\title{
MODEL PENGEMBANGAN KBK BERORIENTASI KKNI DAN PENDIDIKAN KARAKTER BUDAYA AKADEMIK DI FAKULTAS EKONOMI UNIVERSITAS NEGERI MEDAN
}

\author{
Thamrin ${ }^{1)^{*}}$ \\ 1) Fakultas Ekonomi, Universitas Negeri Medan \\ *Penulis korespondensi: thamrinpjt@gmail.com
}

\begin{abstract}
Penelitian ini bertujuan untuk memperbaiki kualitas pendidikan dan pembelajaran melalui pengembangan KBK berorintasi KKNI dan pendidikan karakter budaya akademik. Secara khusus tujuan penelitian ini adalah : Mengembangkan model perancangan KBK berorientasi KKNI dan pendidikan karakter budaya akademik di FE Unimed yang meliputi beberapa tahapan yaitu : a). menyusun capaian pembelajaran fakultas (Faculty Learning Outcames) yang diturunkan dari visi dan misi fakultas yang mengandung profil umum lulusan sebagai competitive dan comparative advantage dari Fakultas Ekonomi. Capaian pembelajaran FE berorientasi KKNI dan lebih menampilkan Karakter Budaya Akademik yang harus dimiliki lulusan. b). merumuskan profil lulusan program studi. c). Perumusan standar kompetensi lulusan, yaitu menentukan kompetensi apa yang harus dimiliki oleh mahasiswa setelah lulus program studi tertentu di FE Unimed berdasarkan profil yang telah ditetapkan. d). perumusan capaian pembelajaran program studi (program learning outcomes/PLO). Capaian pembelajaran dirumuskan berdasarkan hasil tracer study (study pelacakan) dan analisis kebutuhan dunia kerja yang terkait dengan kompetensi yang dibangun, serta jenjang kualifikasi yang diacu dari KKNI, e). capaian pembelajaran mata kuliah (Course learning outcomes/CLO), yaitu dengan menjawab pertanyaan apa yang akan mahasiswa ketahui dan apa yang dapat dilakukan mahasiswa diakhir perkuliahan. f). merumuskan konsep kunci dan kata kunci capaian pada capaian pembelajaran mata kuliah. Mengembangkan model pendidikan karakter budaya akademik di FE Unimed. Pendekatan dalam penelitian ini adalah pendekatan penelitian dan pengembangan (R\&D), digunakan juga kombinasi penelitian kualitatif dan kuantitatif. Sedangkan metode yang digunakan adalah metode penelitian campuran yaitu metode deskriptif - eksploratif yang digunakan untuk mengidentifikasi berbagai gejala dan akar permasalahan yang terjadi dalam pengembangan KBK berorientasi KKNI dan pendidikan karakter budaya akademik.
\end{abstract}

Key Words : Model pengembangan KBK, KKNI dan Pendidikan Karakter 


\section{PENDAHULUAN}

Kurikulum dapat dimaknai sebagai suatu dokumen atau rencana tertulis mengenai kuantitas pendidikan yang harus dimiliki oleh peserta didik melalui suatu pengalaman belajar. Dokumen atau rencana tertulis itu berisikan pernyataan mengenai kualitas yang harus dimiliki seorang peserta didik/mahasiswa yang mengikuti kurikulum tersebut. (Rohman,2012).

Kurikulum merupakan salah satu komponen pendidikan yang cukup berpengaruh terhadap keberhasilan pelaksanaan pendidikan. Kurikulum dikatakan efektif manakala kurikulum tersebut mampu menyiapkan lulusan sesuai kepentingan masyarakat. (Schmidt dalam Festiyed. 2012). Terciptanya lulusan yang dapat memenuhi kebutuhan masyarakat ditentukan berbagai faktor, misalnya kompetensi pendidik, kemampuan peserta didik, sarana, fasilitas, kurikulum, proses pembelajaran dan lain-lain.

Namun, kenyataannya bahwa hasil pendidikan di perguruan tinggi masih cenderung berorientasi pada kemampuan daya ingat untuk menguasai materi yang diberikan semata serta tidak mengembangkan kemandirian peserta didik. Hasilnya pendidikan kita tidak mempunyai makna dan lulusan perguruan tinggi banyak yang menganggur.

Hasil Survei Sosial Ekonomi Nasional (Susenas) oleh Badan Pusat Statistik (BPS) Maret 2010 menyebutkan bahwa jumlah penduduk miskin di Sumatera Utara sebanyak 1,4997 juta atau 11,51 persen. Angka pengangguran berada pada kisaran 10,8\% sampai dengan $11 \%$ dari tenaga kerja yang masuk kategori sebagai pengangguran terbuka. Dari jumlah tersebut 512.825 orang diantaranya adalah sarjana. Terbatasnya lapangan pekerjaan yang tersedia telah meningkatkan jumlah pengangguran. Bahkan mereka yang lulus perguruan tinggi semakin sulit mendapatkan pekerjaan karena tantangan dan persaingan global pasar tenaga kerja nasional maupun Internasional yang semakin terbuka. Dalam keadaan seperti ini maka masalah pengangguran termasuk yang berpendidikan tinggi akan berdampak negatif terhadap stabilitas sosial dan kemasyarakatan.

Tingginya angka pengangguran pada lulusan perguruan tinggi menunjukkan proses pendidikan di perguruan tinggi kurang menyentuh persoalan-persoalan nyata didalam masyarakat. Hal ini bisa jadi disebabkan karena
JURNAL NIAGAWAN Vol 6 No 2 Oktober 2017 sistem pembelajaran yang diterapkan di berbagai perguruan tinggi saat ini.

FE Unimed terdiri dari program studi pendidikan ekonomi, manajemen dan akuntansi memiliki 2.500 mahasiswa yang setiap tahun menghasilkan 500 lulusan. Berdasarkan hasil tracer study dan evaluasi diri FE menunjukkan bahwa masa tunggu mendapatkan pekerjaan rata-rata lebih dari satu tahun dan pekerjaan yang dilakukan tidak sesuai dengan keahlian yang dimiliki oleh lulusan. Jika kondisi ini terus dibiarkan maka dikhawatirkan lulusan dari FE Unimed akan menambah jumlah pengangguran pendidikan tinggi.

Salah satu upaya yang dapat dilakukan adalah dengan melakukan penyempurnaan kurikulum. Kurikulum yang diimplementasikan adalah Kurikulum Berbasis Kompetensi (KBK) yang berorientasi pada Kerangka Kualifikasi Nasional Indonesia (KKNI) dan pendidikan karakter budaya akademik.

KKNI merupakan perwujudan mutu dan jati diri Bangsa Indonesia terkait dengan sistem pendidikan nasional, sistem pelatihan kerja nasional serta sistem penilaian kesetaraan capaian pembelajaran nasional, yang dimiliki Indonesia untuk menghasilkan sumberdaya manusia nasional yang bermutu dan produktif. Kebutuhan Indonesia untuk segera memiliki KKNI sudah sangat mendesak mengingat tantangan dan persaingan global pasar tenaga kerja nasional maupun internasional yang semakin terbuka. Pergerakan tenaga kerja dari dan ke Indonesia tidak lagi dapat dibendung dengan peraturan atau regulasi yang bersifat protektif.

Oleh karena itu, agar dalam jangka pendek dan jangka panjang bangsa Indonesia mampu bertahan tetapi tetap bergerak maju di arena ekonomi global, maka pengakuan timbal balik dan setara antara kualifikasi dan capaian pembelajaran yang dimiliki tenaga kerja Indonesia dengan negara asing menjadi butir-butir yang kritis dalam pengembangan suatu kerangka kualifikasi tenaga kerja nasional. Keselarasan mutu dan penjenjangan antara produk lulusan perguruan tinggi dengan kriteria tenaga kerja yang diharapkan oleh masyarakat pengguna lulusan perlu diwujudkan dengan segera. Keluhan terhadap kesenjangan antara jumlah, mutu, kemampuan lulusan terhadap kriteria yang dibutuhkan oleh dunia kerja sering mengemuka. Perdebatan apakah gelar/ijasah atau sertifikat kompetensi yang lebih bermakna 
untuk mencerminkan kualifikasi pencari kerja sering tidak menemui titik temu yang saling menguntungkan. Permasalahan relevansi pendidikan tinggi seringkali menjadi permasalahan yang mengakar pada dua hal, yaitu: (i) tidak memadainya asupan informasi balik dari pengguna lulusan terkait dengan kebutuhan jumlah, mutu, dan kemampuan lulusan kepada pengelola pendidikan tinggi dan (ii) tidak adanya peta perencanaan modal sumberdaya insani (human capital planning) yang komprehensif secara nasional.

Selanjutnya Mitsubishi Research Institute (2002) meneliti bahwa faktor yang memberikan kontribusi keberhasilan dalam dunia kerja adalah $10 \%$ faktor financial, $20 \%$ keahlian, 30\% ner working dan $40 \%$ faktor soft skills dan karakter. Pendidikan karakter budaya akademik merupakan upaya untuk membangun nilai-nilai dan norma-norma yang menampilkan suasana akademik, yaitu suasana yang menampilkan perilaku sesuai nilai-nilai dan kaidah-kaidah ilmiah dalam upaya memperoleh dan mengembangkan pengetahuan dan mencari kebenaran. Suasana tersebut mutlak dilakukan, dipelihara, dan dibina di perguruan tinggi, sehingga disebut dengan pendidikan karakter budaya akademik di perguruan tinggi. (Menanti ; 2012)

Di dalam pendidikan karakter budaya akademik tersebut mengandung implementasi nilai-nilai seperti nilai-nilai moral, akhlak, budi pekerti, kebenaran, kejujuran, sehingga membangun suasana dan pelaku-pelaku akademis yang bermoral, berakhlak, berbudi pekerti, bernilai kejujuran, kebenaran dalam pemikiran dan perbuatan. Pendidikan karakter budaya akademik di lingkungan perguruan tinggi berpedoman pada tema pembangunan karakter bangsa, yaitu membangun generasi yang jujur, cerdas, tangguh, dan peduli (Kementerian Pendidikan Nasional Direktorat Jenderal Pendidikan Tinggi, 2011).

Di FE Unimed sejak Tahun 2005 telah diterapkan KBK dan tahun 2007 telah dilakukan penguatan terhadap KBK dan 2008 KBK sistem blok. Namun KBK berorientasi KKNI belum pernah dirumuskan padahal KKNI ini sangat mendesak untuk diterapkan sesuai dengan fenomena yang telah digambarkan di atas. Berdasarkan kondisi inilah urgensinya penelitian ini harus dan mendesak untuk dilaksanakan.

Berkenaan dengan masalah pengangguran dari lulusan PT ini, Kementerian Pendidikan
JURNAL NIAGAWAN Vol 6 No 2 Oktober 2017 Nasional melalui Direktorat Jenderal Pendidikan Tinggi telah menggulirkan beberapa terobosan. Salah satu diantaranya adalah penyempurnaan kurikulum. Amanat Peraturan Pemerintah No.17/2010. Pasal 97 menyatakan bahwa kurikulum perguruan tinggi dikembangkan dan dilaksanakan berbasis kompetensi (KBK). Implementasi KBK ini telah terlaksana di FE Unimed. Namun kenyataan masih banyak kendala yang dihadapi terutama tentang penetapan model pembelajaran dengan penerapan pendidikan karakter budaya akademik. Disisi lain Pemerintah telah menerbitkan Perpres No. 8 tahun 2012 tentang Kerangka Kualifikasi Nasional Indonesia (KKNI) untuk menjadi acuan dalam penyusunan capaian pembelajaran lulusan setiap jenjang pendidikan secara nasional yang merupakan upaya melakukan kualifikasi terhadap lulusan Perguruan Tinggi. FE Unimed seyogianya merespon isyarat Perpres tentang KKNI ini agar lulusan FE Unimed memiliki kualifikasi tertentu sesuai KKNI. Namun kenyataannya Unimed secara umum dan FE secara khusus belum mendesain kurikulum yang berorientasi pada KKNI. Sehubungan dengan ini peneliti akan mendesain model pengembangan KBK berorientasi KKNI dan pendidikan karakter budaya akademik.

\section{TINJAUAN PUSTAKA}

Penelitian ini dilaksanakan untuk memperbaiki kualitas pendidikan dan pembelajaran melalui perbaikan KBK yang telah berjalan selama ini dengan berorientasi KKNI dan penddikan karakter budaya akademik.

Secara lebih operasional penelitian ini bertujuan untuk :

1. Mengembangkan model perancangan KBK berorientasi KKNI dan pendidikan karakter budaya akademik di FE Unimed yang meliputi beberapa tahapan yaitu :

a. Merumuskan profil lulusan program studi. Profil lulusan adalah peran yang diharapkan dapat dilakukan oleh lulusan program studi di masyarakat/dunia kerja yang merupakan outcomes pendidikan yang akan dituju.

b. Perumusan standar kompetensi lulusan, yaitu menentukan kompetensi apa yang harus dimiliki oleh mahasiswa setelah lulus program studi tertentu di FE Unimed berdasarkan profil yang telah ditetapkan. 
$\begin{array}{lrcr}\text { c. } & \text { Perumusan } & \text { capaian } & \text { pembelajaran } \\ \text { program } & \text { studi } & \text { (program } & \text { learning }\end{array}$ outcomes/PLO). Capaian pembelajaran dirumuskan berdasarkan hasil tracer study dan analisis kebutuhan dunia kerja yang terkait dengan kompetensi yang dibangun, serta jenjang kualifikasi yang diacu dari KKNI.

d. Merumuskan capaian pembelajaran mata kuliah (Course learning outcomes/CLO), yaitu dengan menjawab pertanyaan apa yang akan mahasiswa ketahui dan apa yang dapat dilakukan mahasiswa diakhir perkuliahan.

e. Merumuskan konsep kunci dan kata kunci capaian pada capaian pembelajaran mata kuliah.

2. Pengembangan Model Recana Program dan Kegiatan Pembelajaran dengan tahapan sebagai berikut:

a. Tahap Perencanan : RKBM (Rencana Kegiatan Belajar Mengajar) yang meliputi Pengembangan Silabus/GBPP dan RPP berbasis pendidikan karakter budaya akademik.

b. Tahap pelaksanaan : Pendekatan pembelajaran yang meliputi menyusun materi ajar, model dan metode pembelajaran dengan penekanan pada pendidikan karakter budaya akademik.

c. Tahap Evaluasi : penilaian yang dituangkan melalui rubrik penilaian dengan memperhatikan aspek content dan performance.

3. Mengembangkan model pendidikan karakter budaya akademik di FE Unimed dan menguji model tersebut melalui penerapan dalam perkuliahan.

Berdasarkan paparan tersebut di atas, penelitian ini menjadi sangat urgen dengan melihat kondisi bahwa jumlah lulusan yang meningkat setiap tahun sedangkan peluang memperoleh kesempatan kerja semakin menurun sehingga tingkat pengangguran kelompok intelektual cukup tinggi. Pada tahun 2010 jumlah pencari kerja terdaftar untuk tingkat pendidikan sarjana di Propinsi Sumatera Utara adalah 187.479 orang (BPS, 2010).

Tingginya jumlah angkatan kerja yang dihasilkan oleh perguruan tinggi, yang belum mendapatkan pekerjaan, dan atau tidak sesuainya bidang pekerjaan dengan kualifikasi yang dimiliki memperkuat indikasi adanya kesenjangan antara mutu dan keterampilan lulusan dengan standar kualifikasi yang dibutuhkan oleh para pengguna.

Pengembangan kurikulum yang sudah dilakukan perlu didesain kembali
JURNAL NIAGAWAN Vol 6 No 2 Oktober 2017 pelaksanaannya sehingga ditemukan model pengembangan kurikulum yang dapat menciptakan lulusan yang kompeten sesuai dengan KKNI dan memiliki karakter budaya akademik yang baik. Penelitian ini juga menjadi sangat penting karena kurikulum yang diterapkan di FE Unimed belum berorientasi pada KKNI disisi lain Peraturan Presiden Republik Indonesia Nomor 8 tahun 2012 tentang KKNI dan Permendikbud No.73 tahun 2013 tentang penerapan KKNI bidang Pendidikan Tinggi, mengisyaratkan perlunya penyempurnaan kurikulum di Perguruan Tinggi berbasis pada KKNI. Karena itu perlu dirancang desain model pengembangan KBK yang berorientasi KKNI dan pendidikan karakter budaya akademik di FE Unimed.

KBK dalam dunia pendidikan di Indonesia mulai diterapkan sejak tahun 2004 dan tahun 2005 telah mulai diterapkan di FE Unimed. Dewasa ini kehidupan manusia dengan cepat berubah dari waktu kewaktu. Dilain pihak dengan kemajuan di bidang komunikasi peserta didik/mahasiswa lebih banyak dipengaruhi oleh faktor-faktor dari luar. Saat ini kehidupan kita senantiasa dibayangi oleh perkembangan IPTEKS dengan akselarasi laju yang luar biasa yang menyebabkan terjadinya ledakan informasi (Rohman,2012). Akibatnya pengetahuan dalam bidang tertentu menjadi kadaluwarsa hanya dalam tempo 2.5 tahun. Hamioyo (dalam Rohman,2012). Dari gambaran di atas jelas bahwa dunia yang dihadapi mahasiswa pada saat ini, sangat kompleks. Wajarlah jika secara periodik kurikulum senantiasa harus selalu ditinjau dan disempurnakan kembali dan senantiasa ada pembaharuan di bidang kurikulum.

Kurikulum pendidikan tinggi hari ini menerapkan KBK yang mengacu pada SK Mendiknas No.045/U/2002 tentang kurikulum inti Perguruan Tinggi yang mengemukakan "Kompetensi adalah seperangkat tindakan cerdas, penuh tanggung jawab yang dimiliki seseorang sebagai syarat untuk dianggap mampu oleh masyarakat dalam melaksanakan tugastugas di bidang pekerjaan tertentu”.

Untuk mengembangkan dan mengimplementasikan KBK ini dengan baik sejumlah komponen perlu terlibat secara inten dan memberikan perannya masing-masing sesuai dengan kapasitasnya antara lain: (a). Visi dan misi kelembagaan dan kepemimpinan yang berorientasi kualitas dan akuntabilitas serta peka 
terhadap dinamika pasar, (b). Partisipasi seluruh sivitas akademika (dosen dan mahasiswa) dalam bentuk shared vision dan mutual commitment untuk optimasi kegiatan pembelajaran, (c). Keterlibatan kelompok masyarakat pemrakarsa (stakehoders) serta masyarakat pengguna lulusan (Rohman,2012).

Sejalan dengan kurikulum ini pemerintah telah mengeluarkan Perpres No.8/2012 tentang KKNI. Kerangka Kualifikasi Nasional Indonesia merupakan mutu dan jati diri Bangsa Indonesia terkait dengan sistem pendidikan nasional, sistem pelatihan kerja nasional serta sistem penilaian kesetaraan capaian pembelajaran nasional, yang dimiliki Indonesia untuk menghasilkan sumberdaya manusia nasional yang bermutu dan produktif (Dirjen Dikti,2010). Kebutuhan Indonesia untuk segera memiliki KKNI sudah sangat mendesak mengingat tantangan dan persaingan global pasar tenaga kerja nasional maupun internasional yang semakin terbuka.

Besarnya jumlah pengangguran merupakan alasan yang sangat tepat bagi pemerintah untuk segera melakukan penyelarasan luaran pendidikan dengan dunia kerja. KKNI sebagai perwujudan mutu dan jati diri bangsa Indonesia dalam sistem pendidikan nasional, sistem pelatihan kerja nasional serta sistem pengakuan kompetensi nasional, KKNI dimaksudkan sebagai pedoman untuk:

a. Menetapkan kualifikasi capaian pembelajaran yang diperoleh melalui pendidikan formal, nonformal,informal, pelatihan atau pengalaman kerja

b. Menetapkan skema pengakuan kualifikasi capaian pembelajaran yang diperoleh melalui pendidikan formal, nonformal,informal.

c. Menyetarakan kualifikasi antara capaian pembelajaran yang diperoleh melalui pendidikan formal,nonformal,informal, pelatihan atau pengalaman kerja

d. Mengembangkan metode dan sistem pengakuan kualifikasi sumberdaya manusia dari negara lain yang akan bekerja di Indonesia (Dirjen Dikti,2010)

Indonesia telah melakukan komparasi tentang kerangka kualifikasi antara lain adalah Australia, Hongkong, Malaysia, Selandia Baru, Singapura, Thailand dan Philipina. Dari berbagai komparasi ini telah dirumuskan penjenjangan KKNI melalui 4 jejak jalan yang menjadi parameter utama yaitu a. Keterampilan kerja, b. Cakupan keilmuan, c. Metode dan tingkat kemampuan, d.
JURNAL NIAGAWAN Vol 6 No 2 Oktober 2017 Kemampuan Manajerial. Ke empat parameter yang terkandung dalam masing-masing jenjang disusun dalam bentuk deskripsi yang disebut deskriptor KKNI yang terdiri dari 9 jenjang deskriptor spesifik.

Dalam penerapan KBK berorientasi KKNI yang tidak kalah pentingnya adalah penerapan pendidikan karakter budaya akademik. Pendidikan karakter budaya akademik di lingkungan perguruan tinggi berpedoman pada tema pembangunan karakter bangsa, yaitu membangun generasi yang jujur, cerdas, tangguh, dan peduli (Kementerian Pendidikan Nasional Direktorat Jenderal Pendidikan Tinggi, 2011). Karakter jujur di perguruan tinggi antara lain diperlihatkan dengan perilaku jujur dalam menghasilkan gagasan ilmiah. Pada mahasiswa, kejujuran ilmiah ditunjukkan oleh perilaku menyelesaikan tugas-tugas yang diberikan oleh dosen seperti membuat makalah, menjawab soal-soal, menyusun skripsi, tesis, dengan menggunakan usaha diri sendiri di bawah pembinaan dosen. Artinya, mahasiswa menjauhkan diri dari perbuatan-perbuatan tidak jujur seperti menyontek, plagiat, meminta teman atau orang lain untuk menyelesakan tugas dirinya, melimpahkan tugas kelompok kepada teman lain (tidak turut menanggungjawapi tugas kelompok).

Karakter cerdas ditunjukkan oleh perilaku tajam pikiran (pandai) dalam mempelajari ilmu pengetahuan, dalam membaca dan menguasai situasi yang dihadapi, mengambil keputusan, dan dalam memajukan diri. Karakter tangguh ditunjukkan oleh perilaku ulet dalam mencapai sesuatu yang diinginkan atau dicita-citakan. Tidak berputus asa meskipun banyak hambatan dan tantangan yang dihadapi. Hambatan dipandang sebagai suatu tantangan yang harus dihadapi dan diselesaikan, tidak dijadikan sebagai alasan menyerah. Karakter peduli ditunjukkan dengan menghiraukan, memberi perhatian pada kebutuhan, kepentingan, dan kesulitan orang lain serta mau membantu orang lain yang mengalami kesulitan tanpa harus diminta. Di lingkungan pendidikan tinggi, hal ini diperlihatkan oleh mahasiswa dengan memberi bantuan kepada mahasiswa yang sulit menguasai materi perkuliahan, membantu mencari sumber-sumber buku, jurnal, dan karya ilmiah lain yang diperlukan oleh mahasiswa lain, bersedia meminjamkan buku, catatan. Bersedia meluangkan waktu untuk 
kegiatan-kegiatan kepentingan kelompok/kelas, seperti menyelesaikan tugas-tugas kelompok, mengadakan seminar mahasiswa, menyampaikan informasi-informasi kepada mahasiswa, ikut serta dalam kegiatan dosen melakukan kegiatan penelitian, dan pengabdian kepada masyarakat.

Ada banyak nilai (value) yang penting dikembangkan untuk mahasiswa . Dari banyak nilai tersebut terdapat nilai-nilai utama (unggulan) yang harus dikembangkan. Nilainilai unggulan karakter budaya akademik yang dikembangkan di FE Universitas Negeri Medan sejalan dengan nilai karakter utama di Unimed sebagaimana yang tertuang dalam buku pengembangan karakter budaya akademik Unimed antara lain:

1. Jujur, dapat dipercaya (trustworthiness) 2. Berlaku hormat (res3. Tanggung jawab (responsibility)3. Berlaku adil (fairness)4. Kepedulian (caring)5. Kewargaan (citizenship7. Toleransi 8.Kerja keras dan tangguh 9. Harga diri (martabat diri) 10. Religius 11. Cerdas. Model pendidikan karakter budaya akademik ini diterapkan dengan tiga pendekatan yaitu 1 . Terintegrasi dalam setiap pembelajaran. 2 . Berbasis komunitas (ekstrakurikuler) dan 3.Cultur akademik (Menanti ; 2012).

\section{METODE PENELITIAN}

Penelitian ini menggunakan pendekatan penelitian dan pengembangan (R\&D), dengan melakukan kombinasi penelitian kualitatif dan kuantitatif dengan metode penelitian campuran. Metode yang digunakan yaitu metode deskriptif - eksploratif untuk merumuskan profil lulusan program studi, Learning outcomes, Stndar kompetensi lulusan, Program learning outcomes dan Course learning outcomes.

Penelitian ini dilakukan di Fakultas Ekonomi Universitas Negeri Medan.

Bagan alir penelitian yang menggambarkan apa yang dilakukan oleh peneliti sebagaimana pada gambar 1 dan diagram tulang ikan pada gambar 2 .
JURNAL NIAGAWAN Vol 6 No 2 Oktober 2017

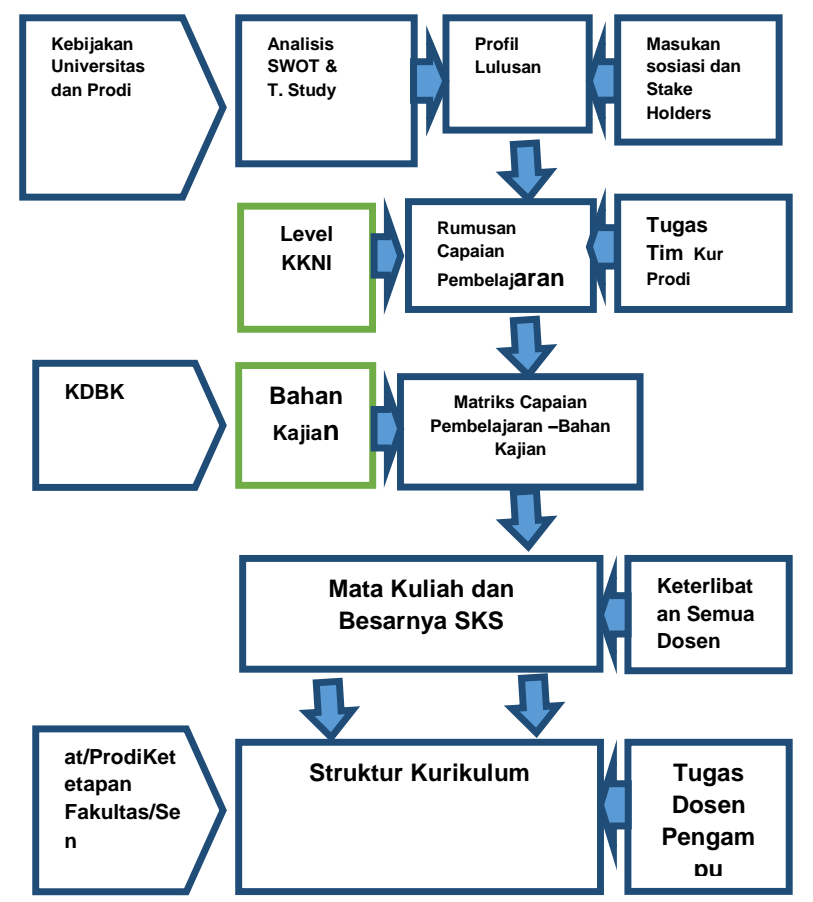

Gambar.1. Bagan Alir Penelitian

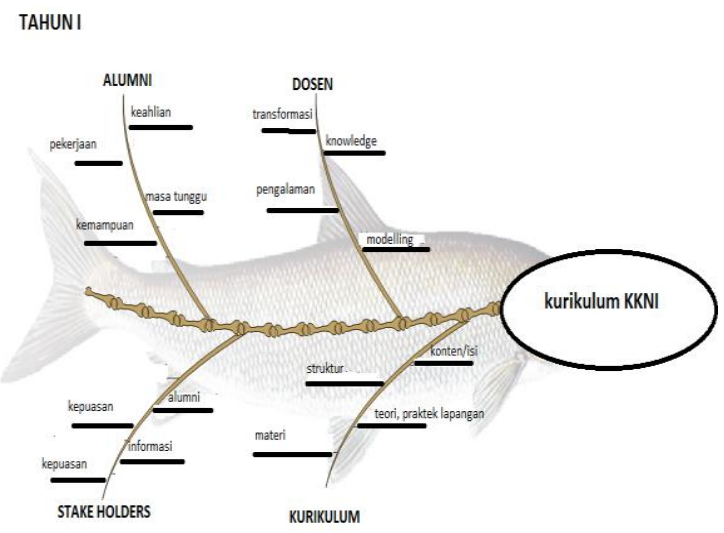

Gambar.2. Diagram Tulang Ikan

Pengumpulan data dalam penelitian dan pengcmbangan ini dikelompokkan menjadi tiga tahapan yaitu studi pendahuluan, pengcmbangan, dan uji validasi. Dalam setiap tahap penelitian dipilih teknik pengumpulan data tertentu sesuai dengan tujuan masing-masing. Pada studi pendahuluan. dipilih teknik kuesioncr/angket,observasi dan dokumemasi, disamping kajian literatur (literature review). Secara umum kctiga, teknik tersebut (kuesioner, dokumentasi dan observasi serta wawancara) digunakana secara bcrsamaan dan saling melengkapi. Angket/kuesioner, terutama digunakan untuk mengungkap: (1) Kondisi Studi, (2) Riwayat pekerjaan pertama sekali dan Sekarang (3).Pengetahuan dan keterampilan yang dimiliki (4) Tingkat keterpakaian pengetahuan dan keterampilan tersebut dalam pekerjaan (5). Komentar terkait Perkuliahn selama ini di FE Unimed (6). Nilai-nilai 
Karakter yang perlu di kembangkan bagi mahasiswa yang mendukung dunia kerja.

Dokumentasi terutama digunakan untuk mclihat mekanisme perumusan kurikulum, penyusunan profil, standart kompetensi, struktur kurikulum di masing-masing prodi, dokumen RKBM (silabus, RPP dan Kontrak perkuliahan), Model pembelajaran dan evaluasi yang diterapkan sselama ini. Observasi dan wawancara dilaksanakan untuk mengungkap bagaimana penerapan model pembelajaran SCL yang diterapkan dalam kurikulum KBK selama ini dan pengintegrasian karakter budaya akademik dalam pembelajaran maupun diluar pembelajaran.

Pada tahap pengembangan, ada dua langkah yang berkaitan dengan teknik pengumpulan data, yaitu dengan melakukan FGD I dan FGD II untuk merumuskan Standart Kompetensi Lulusan dan Learning outcomes, Bahan kajian, Matriks capaian bahan kajian dan struktur Kurikulum. Pada tahap Validasi dilakukan adalah melalui ahli kurikulum dan praktisi atas struktur kurikulum yang telah tersusun.

Analisis data dalam penelitian ini dijelaskan dalam tiga tahap, yaitu tahap pendahuluan, pengembangan dan validasi. Pada tahap studi pendahuluan temuan tentang fakta-fakta (1) Kondisi Studi, (2) Riwayat pekerjaan pertama sekali dan Sekarang (3).Pengetahuan dan keterampilan yang dimiliki (4) Tingkat keterpakaian pengetahuan dan keterampilan tersebut dalam pekerjaan (5). Komentar terkait Perkuliahn selama ini di FE Unimed (6). Nilainilai Karakter yang perlu di kembangkan bagi mahasiswa yang mendukung dunia kerja dideskripsikan dan dianalisis serta diinterpretasikan secara kualitatif. Dengan pendekatan ini maka analisis yang digunakan dalam tahap ini adalah analisis deskriptif kualitatif.

Pada tahap pengembangan dan validasi, pendekatan analisis yang digunakan adalah deskriptif dalam bentuk sajian data demikian juga dalam hal penerapan model dan struktur kurikulum yang dihasilkan divalidasi oleh tim ahli dan praktisi yang dianalisis melalui cek list dan dideskripsikan secara kualitatif. Secara lengakap desain peneletian ini dapat dilihat pada Gambar.3.
JURNAL NIAGAWAN Vol 6 No 2 Oktober 2017

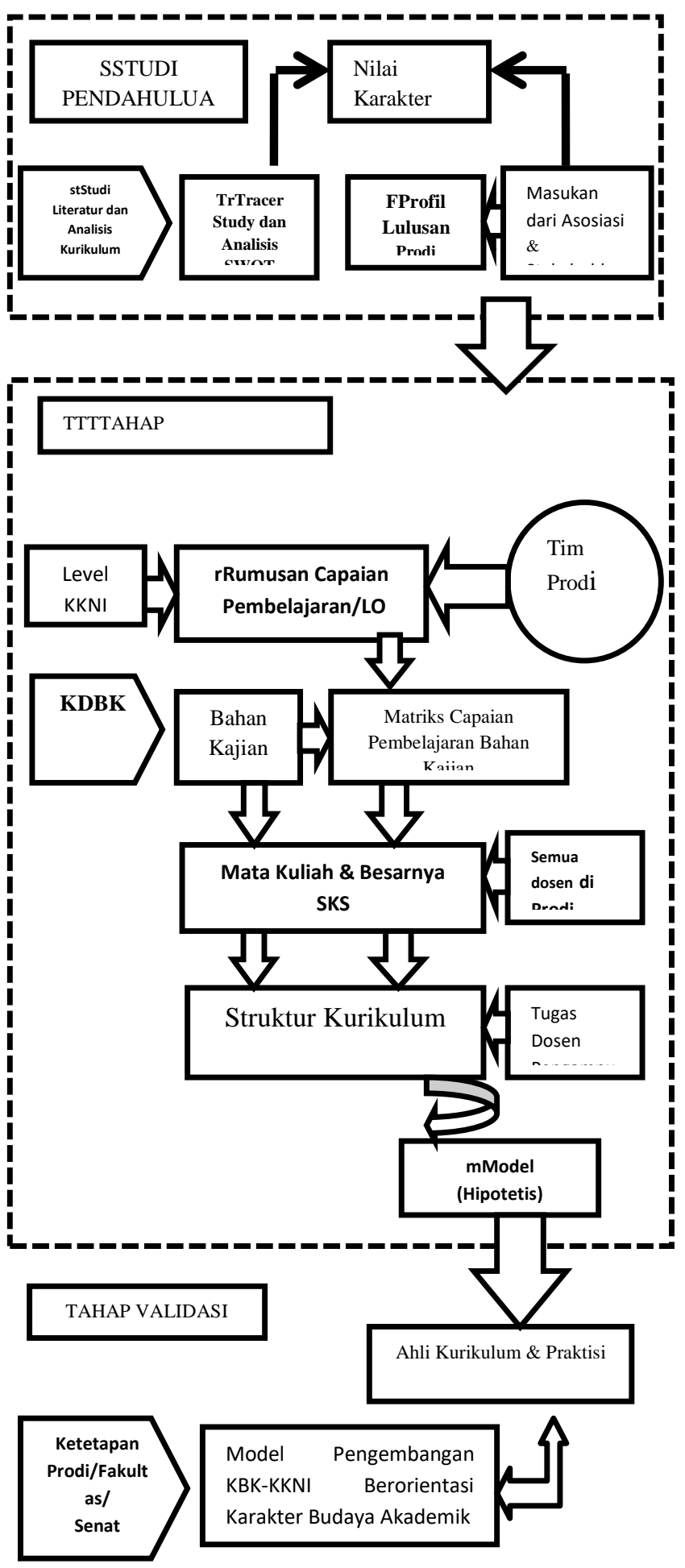

Gambar.3.Tahapan Penelitian Model Pengembangan KBK-KKNI

\section{HASIL DAN PEMBAHASAN}

\section{A. Hasil Penelitian \\ 1. Temuan hasil studi pendahuluan}

Temuan hasil studi pendahuluan dalam penelitian ini adalah :

a. Masa studi alumni menyelesaikan perkuliahan untuk program studi kependidikan rata-rata 4,3 tahun.

b. Masa tunggu alumni mendapatkan pekerjaan untuk prodi kependidikan rata-rata di bawah satu tahun namun untuk mahasiswa 
program studi non kependidikan (Manajemen dan Akuntansi) masa tunggu mendapatkan pekerjaan satu tahun.

c. Pengetahuan dan keterampilan yang diperoleh oleh alumni selama perkuliahan dari 23 aspek yang ditanyakan ada dua aspek yang dijawab oleh responden yang kurang yaitu kemampuan mempelajari dan menerapkan teknologi baru dan kemampuan berbahasa asing. d. Pengetahuan dan keterampilan yang diperlukan alumni di dunia kerjanya antara lain: Kemampuan

komunikasi interpersonal,kemampuan memepelajari dan menerapkan teknologi baru, kemampuan berbahasa asing, kemampuan bekerja dalam tim, keterampilan menggunakan komputer, percaya diri, inisiatif, kecerdasan/kreatifitas, disiplin, komitmen pada pekerjaan, kemampuan berorganisasi, kepemimpinan dan kematangan.

e. Profil Lulusan dari FE Unimed antara lain : Prodi Pendidikan ekonomi; menjadi guru mata pelajaran ekonomi di tingkat SMA/MA dan SMK serta guru IPS di tingkat SMP. Pengembang program pendidikan di jenjang pendidikanSD/MI,SMP/MTs,SMA/SMK. Prodi Pendidikan Akuntansi; menjadi guru Akuntansi di tingkat SMA/MA/ SMK-BM serta guru IPS di tingkat pendidikan SMP/MTs. Pengembang program pendidikan di jenjang pendidikan SD/MI,SMP/MTs,SMA/SMK. Prodi Pendidikan Tata Niaga; menjadi guru bidang kajian manajemen, kewirausahaan di SMK dan guru IPS di SMP/MTs. Pengembang program pendidikan di jenjang pendidikan SD/MI,SMP/MTs,SMA/SMK. Prodi Pendidikan Administrasi Perkantoran; menjadi guru bidang kajian prodi sekretaris di SMK-BM dan guru IPS di SMP/MTs. Pengembang program pendidikan di jenjang pendidikan SD/MI,SMP/MTs,SMA/SMK. Prodi Akuntansi: menjadi Akuntan, Analis Keuangan Bisnis dan pemerintah Perancang Sistem Informasi Akuntansi dan Enterprener. Prodi manajemen; menjadi manajer di perusahaan dan Enterprener

\section{Tahap pengembangan}

Tahap pengembangan KBK-KKNI dilakukan dengan langkah-langkah sebagai

berikut:
JURNAL NIAGAWAN Vol 6 No 2 Oktober 2017

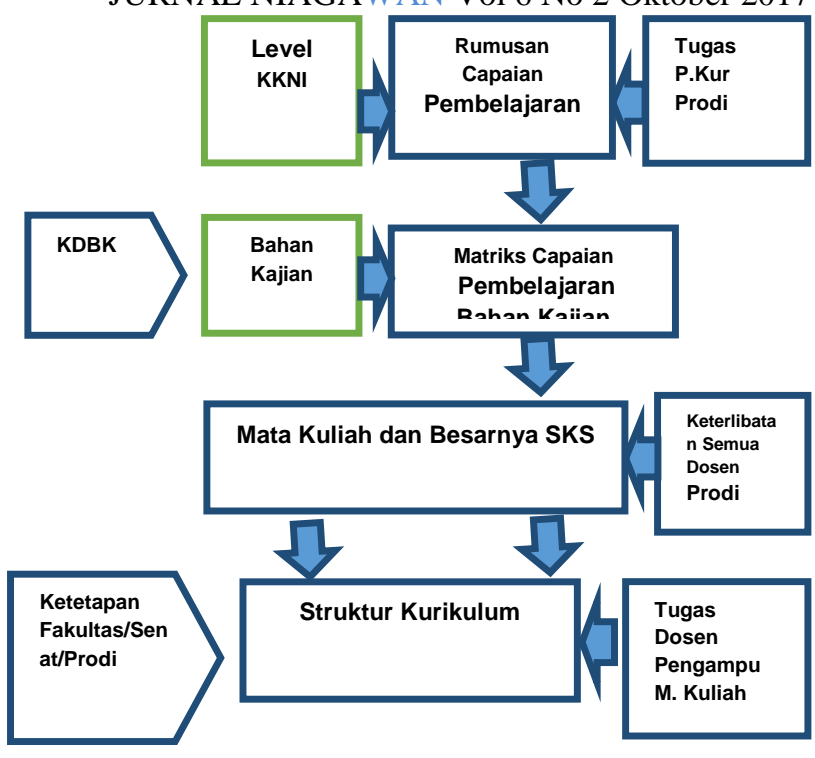

3. Tahap Validasi

Validasi terhadap kurikulum yang telah disusun akan di validasi oleh ahli dan praktisi sesuai bidang keahliannya melalui cek list dan FGD yang dilaksanakan.

4. Nilai-nilai karakter yang diperlukan oleh alumni dalam dunia kerja antara lain:Religi, Jujur, Tanggung jawab, Disiplin, Kreatif, Kepemimpinan, Kerja keras (tangguh), Cerdas, Kerjasama.

\section{B. PEMBAHASAN}

Kurikulum tingkat pendidikan tinggi KBK berbasis KKNI dan Karakter budaya akademaik jika dilihat dari sisi pengelolaan dalam pengembangannya berorientasi pada pendekatan grass-roots. Hal yang mendasarinya adalah bahwa KBK KKNI yang berkarakter perlu memiliki tingkat relevansi yang kuat dengan keberadaan di pasar, baik lokal regional, Nasional maupun Internasional. Selanjutnya dalam pengembangan KBK berbasis KKNI dan Karakter Budaya Akademik perlulah melakukan tracer study dan dukungan dengan alumni dan stakeholders serta asosiasi profesi, asosiasi prodi sejenis terkait dalam rangka menuju relevansi dan kesetaraan kompetensi sesuai dengan levelnya masing-masing baik tingkat Nasional maupun Internasional. Pada tahap internasional perlulah melakukan study banding baik melalui dunia maya maupun secara langsung pada universitas tertentu untuk memperoleh informasi dan masukan dalam penyusunan kurikulum KBK-KKNI.

Hal ini sejalan dengan tujuan pengembangan KKNI secara umum antara lain: (1). Meningkatkan komitmen pemerintah dan masyarakat untuk menghasilkan sumberdaya manusia Indonesia yang bermutu dan berdaya saing Internasional, (2). Mendorong peningkatan 
mutu dan aksesibilitas sumberdaya manusia Indonesia ke pasar kerja nasional dan internasional, (3), Membangun proses pengakuan yang akuntabel dan transparan terhadap capaian pembelajaran yang diperoleh melalui pendidikan formal, non formal, informal, pelatihan atau pengalaman kerja yang diakui oleh dunia kerja secara nasional dan/atau internasional, (4).Mendorong perpindahan pelajar, mahasiswa dan tenaga kerja antara negara berbasis kesetaraan kualifikasi dan tujuan KKNI secara khusus yaitu: (1) Memperoleh korelasi lpositif antara mutu luaran, capaian pembelajaran dan proses pendidikan di perguruan tinggi, (2) Mendorong penyesuaian capaian pembelajaran dan penyetaraan mutu lulusan pendidikan tinggi pada tingkat kualifikasi yang sama, (3).Menjadi pedoman pokok bagi perguruan tinggi dalam mengembangkan mekanisme pengakuan terhadap hasil pembelajaran lampau atau kekayaan pengalaman yang dimiliki seseorang. (4) Menjadi jembatan saling pengertian antara perguruan tinggi dan pengguna lulusan sehingga secara berkelanjutan membangun kapasitas dan meningkatkan daya saing bangsa terutama dalam sektor sumberdaya manusia, (5) Menjamin terjadinya peningkatan aksesibilitas seumberdaya manusia Indonesia ke pasar kerja nasional dan internasional, (6) Memperoleh pengakuan negara-negara lain baik secara bilateral, regional maupun intenasional tanpa meninggalkan ciri dan kepribadian bangsa Indonesia, (7). Memfasilitasi pengembangan mekanisme mobilitas akademik untuk meningkatkan saling pengertia dan solidaritas dan kerjasama pendidikan tinggi antar negara di dunia.

KBK-KKNI berkarkter ini merupakan
upaya unutuk menjawab tantangan era globalisasi saat ini melalui pasar bebasar, sejalan dengan itu pula maka kurikulum haruslah mengimplementasikan pendidikan karakter budaya akademik. Hal ini sejalan dengan pendapat Berkowitz (dalam Megawangi) mengatakan bahwa terjadi peningkatan motivasi siswa/mahasiswa dalam meraih prestasi akademik pada sekolah-sekolah yang menerapkan pendidikan karakter. Pendidikan karakter merupakan pendidikan budi pekerti plus yang melibatkan aspek pengetahuan, perasaan dan tindakan. Dengan pendidikan karakter seorang anak akan menjadi cerdas emosinya yang akan menjadi bekal dalam
JURNAL NIAGAWAN Vol 6 No 2 Oktober 2017 mempersiapkan masa depan dan dengan ini seseorang akan dapat berhasil dalam menghadapi segala macam tantangan, termasuk tantangan untuk berhasil secara akademik.

\section{KESIMPULAN DAN SARAN \\ Kesimpulan}

Berdasarkan hasil penelitian dapat disimpulkan beberapa hal sebagai berikut:

1. Model pengembangan KBK berorientasi KKNI dan Karakter Budaya Akademik meliputi langkah-langkah : (1). Melakukan tracer study dan analisis SWOT, (2). Menerima masukan dari Asosiasi Profesi dan Asosiasi Program Studi sejenis di Universitas lain (3). Melakukukan FGD dengan alumni dan stakeholders untuk merumuskan profil lulusan program studi dan pendidikan karakter, (4). Melakukan FGD dengan seluruh dosen di Prodi untuk merumuskan Learning Outcomes dan merumuskan bidang kajian dengan mengintegrasikan pendidikan karakter berdasarkan hasil tracer study dan FGD (5) Melakukan FGD untuk merumuskan matrik bidang kajian, beban sks mata kuliah dan struktur kurikulum program studi, (6). Melakukan rapat senat untuk meminta masukan, (7). Melakukan Validasi (8). Legalisasi Kurikulum melalui rapat senat dan keputusan pimpinan Fakultas.

2. Berdasarkan hasil tracer study terhadap alumni dan stakeholkers bahwa model pengembangan KBK berorientasi KKNI dan pendidikan karakter ini dapat mengimplementasikan pendidikan karakter dalam kurikulum yang antara lain: Religi, Jujur, Tanggung jawab, Disiplin, Kreatif, Kepemimpinan, Kerja keras (tangguh), Cerdas, Kerjasama.

\section{Saran}

1. Untuk memberhasilkan penyusunan KBK berorientasi KKNI dan Pendidikan Karakter Budaya Akademik Pimpinan Fakultas, Prodi, tim Pengembang dan seluruh dosen di Prodi harus bersinergi secara simultan dan intensif melakukan FGD sesuai tahapantahapan yang telah dirancang dalam model penelitian ini.

2. Tim pengembang Kurikulum dan Ketua Prodi perlu terus secara rutin melakukan komunikasi dengan alumni, stakholder, asosiasi profesi sehingga kurikulum yang 
telah disusun terus dapat diselaraskan dengan keadaan pasar.

3. Untuk mencapai tujuan dari KKNI yang salah satu diantaranya adalah menyandingkan dan mensetarakan alumni dari prodi tertentu yang sejenis dengan alumni dari universitas lain baik tingkat nasional mupun internasional maka perlu dilakukan penelusuran kurikulum di prodi sejenis di Uneversitas lain secara nasional maupun internasional.

\section{REFERENSI}

Dirjen Dikti (2010) Buku Pedoman Kerangka Kualifikasi Nasional Indonesia

Dir.Akademik (2008) Buku Panduan Pengembangan Kurikulum Berbasis Kompetensi.

Fastiyed (2013) Pengembangan Kurikulum MIPA UNP Berbasis KKNI

Rasto (2013) Tahapan Penyelerasan KBK dengan $K K N I$

Menanti (2012) Karakter Budaya Akademik Unimed, Unimed Press

Rohman,M (2012), Kurikulum Berkarakter, Prestasi Pustaka Jakarta

Rasto (2013) Tahapan Penyelerasan KBK dengan KKNI

Sulistyoeati,E, (2012) Implementasi Kurikulum Pendidikan Karakter, Citra Aji Pratama Jogyakarta

Yamin,M. (2012) Panduan Manajemen Mutu Kurikulum Pendidikan,Diva Press Jogyakarta Print, Murray (1993) Curriculum Development and Design. 2nd. NSW Australia Allen \& Unwin Pty.Ltd

Gufron, A. (2009). Pemutakhiran Kurikulum di Perguruan Tinggi (Makalah JIP-FIP)

Sukmadinata, Nana (1997). Pengembangan Kurikulum: Teori dan Praktik: Bandung. Remja Rosda Karya 